\title{
SEEDBORNE BACTERIA OF ORANGE AND BLACK COLOUR CARROTS IN TURKEY
}

\author{
Kubilay K. Bastas, Haris Butt, Aysegul Gur \\ Department of Plant Protection, Faculty of Agriculture, Selcuk University, Campus, Konya, Turkey.
}

\section{ART ICLE INFO}

\section{Article History}

Received: September 17, 2021

Revised: December 20, 2021

Accepted: December 27, 2021

\section{Keywords}

Carrot

Bacteria

Seed

Identification

Xanthomonas hortorum pv. carotae

Pseudomonas viridiflava
A B S T R A C T

Carrot (Daucus carota L.) is among the most economically important vegetable crops worldwide. Seedborne bacterial pathogens of carrot cause important damages to seed quality and yield of plants. In this study, seedborne bacteria were determined on some carrot seeds sown in Turkey. Seeds of different orange and black color varieties of carrot were collected from Eregli and Kasınhanı districts of Konya province, where the highest carrot production is reported. Subsamples of 10,000 seeds were soaked in $100 \mathrm{ml}$ sterile saline $(0.85 \% \mathrm{NaCl})$ with $0.02 \%$ Tween 20 overnight at $5{ }^{\circ} \mathrm{C}, \mathrm{YDCA}, \mathrm{KB}, \mathrm{MKM}, \mathrm{MD} 5 \mathrm{~A}$ and mTBM media were used for bacterial isolation and bacterial morphological characterization. Biochemical, physiological and molecular methods were used for the identification of the bacterial isolates. Pathogenicity tests of strains were performed on orange color carrots, and pathogenic strains induced a hypersensitive reaction in tobacco plants. The 60 pathogenic and saprophytic bacterial strains were obtained belong to Pseudomonaceae, Bacillaceae, and Xanthomonadaceae families. There were twentythree seed samples on 5 different orange carrot cultivars Maestro, Bolero, Sireco, Natuna and Romans, and 11 black carrot genotype of traditional cultivar 'Eregli'. Two pathogenic bacteria were defined as Xanthomonas hortorum pv. carotae and Pseudomonas viridiflava at different percent infestation ratios (17.39-18.18\%) and (9.09-13.04\%) on orange and black carrot seed samples. To the best of our knowledge, it is the first report of $P$. viridiflava on carrot seeds in Turkey.

Corresponding Author: Kubilay K. Bastas

Email: kbastas@selcuk.edu.tr

(C) The Author(s) 2021.

\section{INTRODUCTION}

Carrot (Daucus carota L.) is consumed as edible roots; usually, orange in color but red, white, purple, and yellow varieties also exist. Carrot is native to Europe and southwestern Asia and is a domesticated form of the wild carrot Daucus carota. Selective breeding has been practised for domestic carrot to obtain large, more delectable, and edible taproot with a less woody texture. Most carrot cultivars contain water (88\%), sugar $(7 \%)$, fibre $(1 \%)$, ash $(1 \%)$, protein $(1 \%)$, and fat $(0.2 \%)$ with almost no starch content. The fiber comprises mostly of cellulose, with smaller proportions of hemicellulose and lignin. Fructose, sucrose, glucose and xylose are free sugars found in carrots. Glutamic acid and other free amino acids are responsible for the taste while $\beta$-carotene mainly, and $\alpha$-carotene and $\gamma$ carotene to lesser extent, gives carrot the bright orange colour. In humans, $\alpha$ and $\beta$-carotenes are partly metabolized into vitamin A. Among carotenoid, $\beta$ carotene is the predominant while $\alpha$-carotene and $\gamma$ carotene are present in lesser amounts. Typically, there are between 6000 and 54,000 $\mathrm{g}$ of carotenoids in 100 grams of carrot root. There are abundant amounts of antioxidants and minerals in carrots having anti-aging, anti-inflammatory, antiproliferative, and anticarcinogenic properties. Additionally, carrot 
consumption helps in maintenance of normal blood glucose and cholesterol levels, minimizes the risk of cardiovascular diseases, and protects against diabetes and Alzheimer's disease (Ahmad et al., 2019).

According to the Food and Agriculture Organization of the United Nations (FAO), 44.76 million tonnes of carrots and turnips were produced worldwide in the calendar year 2019 (FAOSTAT, 2019). China led the chart with 21.48 million tonnes that accounted for $47.99 \%$ of the global output, followed by Uzbekistan, the USA and Russia, with almost 2.77, 2.26, and 1.56 million tonnes, respectively. Asia produced about $64.8 \%$ of the world's carrot followed by Europe (19\%) and Americas (10\%). Turkey is among the world's important carrot producers, with its annual production of 663.882 tonnes (TUIK, 2019).

Bacteria, fungi and viruses can be transmitted through seeds in plants (Baker and Smith, 1966; Mundt and Hinkle, 1976). Thus one would expect natural selection to favor host plants that tightly control the kind and number of microbes that migrate into the developing seeds. Carrots are affected by several bacterial diseases; leaf blight (Xanthomonas hortorum pv. carotae), soft rot (Dickeya dadantii, Pectobacterium carotovorum subsp. carotovorum and Pectobacterium atrosepticum), crown gall (Rhizobium radiobacter), hairy root ( $R$. rhizogenes), milky disease (Bacillus popilliae var. rhopaea) and scab (Streptomyces scabies) (Strandberg, 2000). Almeida et al. (2013) reported that Pseudomonas viridiflava was determined on carrot seeds, and this could explain how post-harvest damage might originate from contaminated seeds.

The world's carrot seed industry is concerned directly with a seed-borne disease i.e., bacterial blight, caused by $X$. hortorum pv. carotae. Under optimum conditions, the quality of $X$. hortorum pv. carotae infested carrot seeds may reduce noticeably, which leads to a significant yield loss. Brown stem, blighted umbels, petiole lesions, necrotic leaf spots with irregular yellow halos, and gummy bacterial exudates on stems and umbels are typical symptoms of this disease. Use of $X$. hortorum pv. carotae free seed is important management practice as contaminated carrot seeds can be a potential primary source of inoculum. Therefore, inspection services, seed industry and commercial seed testing laboratories needed sensitive detection methods suitable for routine application (Meijerink and Van Breukelen, 1995). Despite being able to detect the seed-borne infection, development of seed contamination thresholds for specific regions of carrot production (Umesh et al., 1998), and the availability of seed treatments to eliminate seed-borne inoculum (Howard et al., 1994; Pscheidt and Ocamb, 2001), the carrot industry is still facing losses due to this disease (Kuan et al., 1985; Umesh et al., 1996). Studies regarding the prevalence of $X$. hortorum pv. carotae in carrot seeds in Turkey are very scarce and the pathogen was reported only once by Demir and Ustun (2001) in one carrot seed sample in Aegean Region. So it is important to study further the presence of this pathogen in carrot seeds in Turkey.

The pectinolytic species Pseudomonas viridiflava is a multi-host and seed-borne pathogen causing severe damages to tomato (Alivizatos, 1986; Goumas et al., 1999), melon (Aysan et al., 2003) bean, birdsfoot, cabbage, cauliflower, kiwifruit, fennel, grape, lettuce, lupine, parsnip, passion fruit, pea, pepper, poinsettia, poppy, pumpkin, rape, soybean, and zinia, Amaranthus sp., Chrysanthemum sp., eggplant (Goumas et al., 1999), and Arabidopsis thaliana (Goss et al., 2005). Symptoms of $P$. viridiflava infection include yellowing of the plant and inner part of the stem, wilting, brown discoloration of vascular tissses and pith often developing soft rot. Particularly in Aegean islands, this pathogen is significant in the eastern Mediterranean region, representing $50 \%$ and 15\%, respectively, of the Pseudomonas species causing stem necrosis (Aysan, 2001; Ustun and Saygili, 2001).

Seventy percent of Turkey's orange carrots are produced in Kasınhanı town of Konya Province and exports them to the Middle East and Balkans countries. According to the provincial agricultural directorate, 300.000 tons of orange carrot is grown in the region. There are 110 carrot processing factories of varying sizes in Kasınhanı. In addition, an estimated 10,000 workers go to Kasınhanı from neighborhood towns or provinces every year as seasonal laborers. Black carrot is produced about 140,000160,000 tons in only Eregli district of Konya Province, Turkey.

This study aimed to determine the seed-borne bacterial pathogens on seeds of black and orange carrots in the areas with highest production, i.e., Kasınhanı town and Eregli district of Konya.

\section{MATERIAL AND METHODS Plant material}

Seed samples were obtained from carrot producers in 
2 districts (Kaşınhanı and Ereğli) of Konya province of Central Anatolia Region, Turkey. Twenty three seed samples from five different orange carrot cultivars; Maestro, Bolero, Sireco, Natuna and Romans, and 11 black carrot genotypes of traditional cultivar 'Ereğli' were used in the experiments.

For bacterial identification, carrot cv. Maestro and Nicotiana tobaccum cv. White Burley were used for pathogenicity tests and hypersensitivity reaction (HR) assays.

\section{Reference cultures}

Reference cultures used in all the tests are given in Table 1. Stock cultures were preserved at $-80{ }^{\circ} \mathrm{C}$ in $30 \%$ glycerol solution. Colonies grown on NA at $23-25{ }^{\circ} \mathrm{C}$ were used to prepare the bacterial suspensions, adjusted

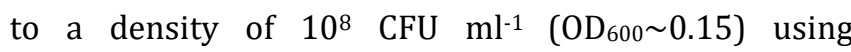
biophotometer (Eppendorph, Germany). Sterile distilled water (SDW) was used for dilutions, and the inoculum was kept on ice and plants were inoculated within $2 \mathrm{hrs}$ of inoculum preparation.

Table 1. Reference cultures and their sources used in the experiments.

\begin{tabular}{|c|c|c|}
\hline Bacterium & Code No & Source \\
\hline Xanthomonas hortorum pv. carotae & NCPPB3651 & Nat. Collec. of Plant Pathogenic Bacteria, England \\
\hline Xanthomonas translucens pv. translucens & XttKk521 & Prof. K. K. Bastas, Selcuk University, Turkey \\
\hline Xanthomonas axonopodis pv. phaseoli & NCPPB2665 & Nat. Collec. of Plant Pathogenic Bacteria, England \\
\hline Pseudomonas viridiflava & YA12 & Prof. Y. Aysan, Cukurova University, Turkey \\
\hline Pseudomonas syringae pv. syringae & Pss74 & Prof. K. K. Bastas, Selcuk University, Turkey \\
\hline $\begin{array}{l}\text { Pectobacterium caratovorum subsp. } \\
\text { caratovorum }\end{array}$ & EccLk7 & Prof. K. K. Bastas, Selcuk University, Turkey \\
\hline Pectobacterium atrosepticum & EcaKp37 & Prof. K. K. Bastas, Selcuk University, Turkey \\
\hline
\end{tabular}

\section{Isolation of bacteria from the seeds}

Seed sample was taken from the bottom of the bag $(100 \mathrm{~g}$ each) and was divided into 5 subsamples of $20 \mathrm{~g}$ seeds each according to the standards of International Seed Testing Association (ISTA) (Asma, 2010).

Twenty-gram seed subsamples (approx. 10.000 seeds) were added to $100 \mathrm{ml}$ of sterile cold $\left(5^{\circ} \mathrm{C}\right.$ ) aqueous saline $(0.85 \% \mathrm{NaCl})$ in $250 \mathrm{ml}$ Erlenmeyer flask. After incubation in dark for $16-18$ hours at $5{ }^{\circ} \mathrm{C}, 0.05 \mathrm{ml}$ of sterile Tween 20 was added to the flasks, and the samples were shaken vigorously for one minute. Afterwards, the suspensions were filtered through sterile cheesecloth. The retained seeds were rinsed with $25 \mathrm{ml}$ of cold sterile saline. The pooled washings were collected in a clean, sterile flask and centrifuged at $4000 \mathrm{rpm}$ for $15 \mathrm{~min}$. Pellets were resuspended in $10 \mathrm{ml}$ of sterile cold saline and the suspensions were diluted to $10^{3}-10^{6}$, and plated onto the following media for $4-8$ days at $28{ }^{\circ} \mathrm{C}$ in triplicate (King et al., 1954; Kim et al., 1982; Williford and Schaad, 1984; Cubeta and Kuan, 1986; Megurre et al., 1986; Lelliott and Stead, 1987; Schaad, 1988; Schaad et al., 2001; Asma, 2010); Nutrient Agar (20 g/L nutrient agar (Merck), 40 mg/L cycloheximide), King's B medium (KB; proteose peptone $20 \mathrm{~g} / \mathrm{L}$, glycerol $15.0 \mathrm{ml} / \mathrm{L}, \mathrm{K}_{2} \mathrm{HPO}_{4} 1.5$ $\mathrm{g} / \mathrm{L}, \mathrm{MgSO}_{4} .7 \mathrm{H}_{2} \mathrm{O} 1.5 \mathrm{~g} / \mathrm{L}$, agar $15 \mathrm{~g} / \mathrm{L}$ ), MD5A medium (0.3 g/L MgSO $4.7 \mathrm{H}_{2} \mathrm{O}, 1 \mathrm{~g} / \mathrm{L} \mathrm{NaH}_{2} \mathrm{PO}_{4}, 1 \mathrm{~g} / \mathrm{L} \mathrm{NH}_{4} \mathrm{Cl}, 3.0 \mathrm{~g} / \mathrm{L}$
$\mathrm{K}_{2} \mathrm{HPO}_{4}$ with $17 \mathrm{~g} / \mathrm{L}$, pH adjusted to 6.4, after autoclaving: $10 \mathrm{mg} / \mathrm{L}$ cephalexin monohydrate, $20 \mathrm{mg} / \mathrm{L}$ nystatin, 1 $\mathrm{mg} / \mathrm{L}$ L-methionine, $10 \mathrm{mg} / \mathrm{L}$ bacitracin, $10 \mathrm{~g} / \mathrm{L}$ filter sterilised cellobiose, and $5 \mathrm{mg} / \mathrm{L} \mathrm{L-glutamic} \mathrm{acid),} \mathrm{mTBM}$ medium $\left(10 \mathrm{~g} / \mathrm{L}\right.$ peptone, $0.3 \mathrm{~g} / \mathrm{L} \mathrm{H}_{3} \mathrm{BO}_{3}, 10 \mathrm{~g} / \mathrm{L} \mathrm{KBr}, 17$ $\mathrm{g} / \mathrm{L}$ agar, $\mathrm{pH}$ adjusted to 7.4 , after autoclaving: $12 \mathrm{mg} / \mathrm{L} \mathrm{5-}$ fluorouracil, $20 \mathrm{mg} / \mathrm{L}$ nystatin, $65 \mathrm{mg} / \mathrm{L}$ cephalexin monohydrate, $10 \mathrm{~g} / \mathrm{L}$ skimmed milk, and $10 \mathrm{ml} / \mathrm{L}$ Tween 80), YDCA medium $\left(20 \mathrm{~g} / \mathrm{L} \mathrm{CaCO}_{3}, 10 \mathrm{~g} / \mathrm{L}\right.$ yeast extract, $20 \mathrm{~g} / \mathrm{L}$ dextrose, $15 \mathrm{~g} / \mathrm{L}$ agar), MKM medium $(1.2 \mathrm{~g} / \mathrm{L}$ $\mathrm{KH}_{2} \mathrm{PO}_{4}, 4 \mathrm{~g} / \mathrm{L} \mathrm{D(+)} \mathrm{trehalose} \mathrm{dihydrate,} 1 \mathrm{~g} / \mathrm{L} \mathrm{NH}_{4} \mathrm{Cl}, 10$ $\mathrm{g} / \mathrm{L}$ lactose monohydrate, $0.2 \mathrm{~g} / \mathrm{L} 2$-thiobarbituric acid with $17 \mathrm{~g} / \mathrm{L}, 0.5 \mathrm{~g} / \mathrm{L}$ yeast extract, $1.2 \mathrm{~g} / \mathrm{L} \mathrm{K}_{2} \mathrm{HPO}_{4}$, pH adjusted to 6.6 , after autoclaving: $2 \mathrm{mg} / \mathrm{L}$ tobramycin sulphate, $20 \mathrm{mg} / \mathrm{L}$ nystatin, $50 \mathrm{mg} / \mathrm{L}$ bacitracin, and 10 $\mathrm{mg} / \mathrm{L}$ cephalexin monohydrate).

Pure culture suspensions of known strains of $X . h$. pv. carotae and $P$. viridiflava were spread on abovementioned media to prepare the positive control plates. Colonies were considered if they appeared similar to colonies of the reference strains.

\section{Identification of the bacteria Biochemical and physiological tests}

Different biochemical tests conducted to characterize the presumptive pathogens are given in Table 2 (Kovacs, 
1956; Thornley, 1960; Klement, 1963; Kuan et al., 1985; Komagata, 1986; Bradbury, 1986; Lelliott and Stead, 1987; Klement et al., 1990).

\section{Pathogenicity and hypersensitivity tests}

Individual plastic pots containing $3 \mathrm{~kg}$ sterile soil were fertilized once with $9.5 \mathrm{~g}$ ammonium sulfate, $9.5 \mathrm{~g}$ diammonium phosphate, $9.5 \mathrm{~g}$ potassium sulfate, and 50 $\mathrm{mL}$ of a liquid humic acid (Kaçar and Katkat, 1999), and they were grown at $25 \pm 5^{\circ} \mathrm{C}, 60-75 \% \mathrm{RH}$, and under 12.000-14.000 Lux from tungsten-filament lamps for a 16-h photoperiod. Five seeds were planted in each pot of each carrot variety 'Maestro' at a depth of $8-10 \mathrm{~mm}$. Four week-old plants were sprayed with distilled water to create a fine humidity by a hand-held laboratory sprayer for bacterial development.

All suspect strains of $X$. $h$. pv. carotae were tested by atomizing the leaves to run off with a bacterial suspension containing $10^{8} \mathrm{CFU} \mathrm{ml}^{-1}$. Inoculated seedlings (five plants per strains) were incubated for $48 \mathrm{~h}$ to enhance infection. After this incubation, plants were set in a cool condition (at $20^{\circ} \mathrm{C}, 16 \mathrm{~h}$ ) before placing the plants in greenhouse conditions at $25-30{ }^{\circ} \mathrm{C}$ with 90\% relative humidity (Kuan, 1989; Asma et al., 2002). After the 15-day incubation period, treated seedlings were observed for pathogenicity based on typical leaves symptoms and intensity of stem necrosis (Taylor, 1970; Lelliott and Stead, 1987). Each strain was inoculated on two carrot plant leaves under same conditions. Finally, SDW and reference strains were sprayed on the control plants.

The inoculation of 26 carrot plants with tuberous roots was done by pricking the crown area of the root with a sterile needle after placing a drop of $P$. viridiflava suspension $\left(10^{8} \mathrm{CFU} \mathrm{ml}^{-1}\right)$ to aid the bacterial entry into the tissues. SDW and reference strains were used to inoculate the control plants by the same method. Afterward, inoculated plants were transferred to a humid chamber for $72 \mathrm{hrs}$ followed by the transfer to the greenhouse. Daily examinations were conducted for 15 days to observe the symptom development. Carrot slices treated with SDW were used as controls.

Eight-week-old tobacco plants (Nicotiana tobaccum var. White Burley) were used to perform HR tests. The bacterial suspension $\left(10^{8} \mathrm{CFU} \mathrm{ml}-1\right)$ or water (control) was injected into the mesophyll cells using a $0.46-\mathrm{mm}$ diam (26-gauge) hypodermic syringe. Treated leaves were marked with numbers of the strains using a permanent pencil for evaluations. Three leaves of each tobacco plant were inoculated with each strain.

\section{Polymerase chain reaction (PCR) assays}

All strains were plated in triplicate onto KB and YPGA agar plates and incubated for $48 \mathrm{hr}$, washed individually three times, each time with $1 \mathrm{ml}$ of SDW. All bacterial strains were streaked on YPGA and KB agar plates in triplicate followed by $48 \mathrm{hrs}$ incubation and suspended in $1 \mathrm{ml}$ of SDW afterward. The suspensions were centrifuged at $10000 \mathrm{~g}$ for 5 minutes to obtain bacterial pellets suspended in $800 \mathrm{ml}$ of

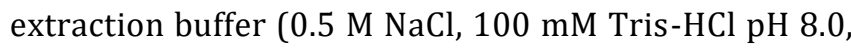
$1 \%$ SDS, $50 \mathrm{mM}$ EDTA) followed by a $30 \mathrm{~min}$ incubation at $65^{\circ} \mathrm{C}$. Then $5 \mathrm{M}$ potassium acetate $(400 \mathrm{ml})$ was added to each reaction and incubated for $20 \mathrm{~min}$ on ice. The reactions were centrifuged at $10000 \mathrm{~g}$ for $10 \mathrm{~min}$, RNase $(40 \mathrm{mg} / \mathrm{ml})$ was added at $37^{\circ} \mathrm{C}$, followed by phenol/chloroform/isoamyl alcohol (25:24:1) extraction, and finally ethanol precipitation. The pellets obtained were suspended in Tris-EDTA (TE) buffer (Goncalves and Rosato, 2002; Nunes et al., 2008). DNA concentrations were measured using Biophotometer Plus (Eppendorf, Germany). Amplifications were carried out in $0.5 \mathrm{ml}$ PCR tubes with a final volume of $25 \mu \mathrm{l}$ in an Eppendorf thermocycler. Reaction mixtures contained: $2 \mu \mathrm{l}$ target DNA, $12.5 \mu \mathrm{l}$ PCR Master Mix (4 $\mathrm{mM} \mathrm{MgCl} 2,0.05$ units / $\mu \mathrm{l}$ Taq DNA, 0.4 mM dGTP, 0.4 $\mathrm{mM}$ dATP, $0.4 \mathrm{mM}$ dTTP, and $0.4 \mathrm{mM}$ dCTP), $2 \mu \mathrm{l}$ each of Forward and Reverse primers, $6.5 \mu \mathrm{l}$ SDW). After amplification, the PCR products were electrophoresed in $1.5 \%$ agarose gel in $1 \times \mathrm{TBE}$ buffer with $1000 \mathrm{bp}$ marker (Fermantas). After staining with ethidium bromide, the gel was visualized using Quantum Gel Visualization System (PrizmaLab, Turkey). (Sambrook et al., 1989: Sambrook and Russell, 2001).

Primers used, 3SF 5' CATTCCAAGAAGCAGCCA3', and 3SR 5' TCGCTCTTAACACCGTCA 3', were specific for $X$. $h$. pv. carotae identification (Meng et al., 2004) amplifies a 350-bp DNA fragment. Reaction conditions applied were: $95{ }^{\circ} \mathrm{C}$ for 5 min (initial denaturation, single-step reaction), $94{ }^{\circ} \mathrm{C}$ for $15 \mathrm{sec}$ ( $35 \mathrm{cycles}$ ), $58{ }^{\circ} \mathrm{C}$ for $15 \mathrm{sec}$, $72{ }^{\circ} \mathrm{C}$ for $30 \mathrm{sec}$. The final extension time was $5 \mathrm{~min}$ at $72{ }^{\circ} \mathrm{C}$ and $20 \mathrm{~min}$ at $20{ }^{\circ} \mathrm{C}$ as a single-step reaction, respectively.

The amplification of $P$. viridiflava was done using specific primers obtained from a 16SrRNA conserved region i.e., PsV-F (5'GTAGGTGGTTTGTTAAGTTGAA'3), and PsV-R 
(5'ACCTCAGTGTCAGTATGAGC'3. Reaction conditions were: $95^{\circ} \mathrm{C}$ for $4 \mathrm{~min}$ (initial denaturation), $95^{\circ} \mathrm{C}$ for 1 $\min \left(35\right.$ cycles), $52^{\circ} \mathrm{C}$ for $1 \mathrm{~min}, 72{ }^{\circ} \mathrm{C}$ for $90 \mathrm{sec}$ followed by $72{ }^{\circ} \mathrm{C}$ for $10 \mathrm{~min}$ (final extension) (Alimi et al., 2011). For efficient and reliable results, the amplifications were repeated twice in separate assays.

\section{Determination of infestation ratios (\%) of the pathogens on seed samples}

The percent infestation for each carrot cultivar [PIP (\%)] was calculated by commensurating the total infested seed samples ( $\Sigma$ ISP) of relevant cultivar with the total collected seed ( $\Sigma \mathrm{SP}$ ) samples for each individual cultivar using following formula;

$$
I C(\%)=\frac{\sum I S P}{\sum S P} \times 100
$$

The percent infestation of all cultivars in same group carrot (orange or black) [TI (\%)] was determined by commensurating the total infested seed samples ( $\Sigma$ ISR) of relevant all cultivars in the same group carrot (orange or black) with the total collected seed samples ( $\Sigma \mathrm{SR}$ ) for that region using the following formula;

$$
T I(\%)=\frac{\sum I S R}{\sum S R} \times 100
$$

\section{RESULTS}

Total 60 bacterial isolates were obtained from twenty three seed lots on 5 different orange carrot cultivars, Maestro, Bolero, Sireco, Natuna and Romans, and 11 black carrot genotype of traditional cultivar 'Ereğli' in Konya province. Identification of bacteria was done by biochemical, morphological, physiological (Table 2) and molecular methods. According to our findings, mainly two pathogenic bacteria were identified as $X$. $h$. pv. carotae (16 strains) and P. viridiflava (13 strains) on orange and black carrot seeds at different percent infestation ratios (Table 3 ).

Table 2. Biochemical and physiological characterization tests used for Pseudomonas viridiflava and Xanthomonas

\begin{tabular}{|c|c|c|c|c|c|c|c|c|c|}
\hline \multirow[t]{2}{*}{ TEST } & \multicolumn{4}{|c|}{ Reference strains } & \multirow{2}{*}{$\begin{array}{l}\text { PV strains } \\
\text { obtained } \\
\text { from seeds }\end{array}$} & \multicolumn{3}{|c|}{ Reference strains } & \multirow{2}{*}{$\begin{array}{c}\text { XHC strains } \\
\text { obtained from } \\
\text { seeds }\end{array}$} \\
\hline & PV & PCC & $\mathrm{PA}$ & PSS & & $\mathrm{XHC}$ & XAP & XTT & \\
\hline Gram reaction & - & - & - & - & - & - & - & - & - \\
\hline Fluorescent pigment on $\mathrm{KB}$ & + & - & - & + & + & - & - & - & - \\
\hline Facultative growth & - & + & + & - & - & - & - & - & - \\
\hline Levan production & - & - & - & + & - & + & + & - & + \\
\hline Oxidase & - & - & - & - & - & + & - & - & - \\
\hline Pectolytic activity & + & + & + & - & + & - & - & - & - \\
\hline Arginine dihydrolase & - & - & - & - & - & - & - & - & - \\
\hline Gelatin hydrolysis & + & + & + & + & + & + & - & + & + \\
\hline Esculin hydrolysis & + & + & - & + & + & + & + & + & + \\
\hline Starch hydrolysis & - & - & - & - & - & + & + & - & + \\
\hline $\begin{array}{l}\mathrm{H}_{2} \mathrm{~S} \text { production from } \\
\text { cysteine }\end{array}$ & - & - & - & - & - & + & + & + & + \\
\hline Nitrate reduction & - & + & + & - & - & - & - & - & - \\
\hline Catalase & + & + & + & + & + & + & + & + & + \\
\hline Urease production & - & - & - & + & - & - & - & - & - \\
\hline Acid production from & & & & & & & & & \\
\hline $\mathrm{D}(-)$ mannitol & + & + & + & + & + & $\mathrm{V}$ & - & + & - \\
\hline inositol & + & - & - & + & + & ND & ND & ND & ND \\
\hline erythritol & + & V & ND & + & + & - & - & & - \\
\hline maltose & - & - & - & + & - & + & - & + & + \\
\hline D(-) arabinose & - & - & - & - & - & - & - & + & - \\
\hline D-sorbitol & + & - & + & + & + & - & - & - & - \\
\hline Sucrose & - & - & + & + & - & + & + & + & + \\
\hline
\end{tabular}
hortorum pv. carotae strains isolated from carrot seeds in comparison with reference and negative strains. 
Growth at $36{ }^{\circ} \mathrm{C}$

Growth at $40{ }^{\circ} \mathrm{C}$

Ice nucleation

HR on tobacco

$\begin{array}{llll}- & + & - & - \\ - & - & - & - \\ - & - & - & + \\ + & + & + & +\end{array}$

$\begin{array}{lll}- & + & + \\ - & - & + \\ - & - & - \\ + & + & +\end{array}$

$\begin{array}{ll}+ & + \\ + & - \\ + & - \\ + & +\end{array}$

PV: Pseudomonas viridiflava, PCC: Pectobacterium caratovorum subsp. caratovorum, PA: Pectobacterium atrosepticum, PSS: Pseudomonas syringae pv. syringae, XHC: Xanthomonas hortorum pv. carotae, XAP: Xanthomonas axonopodis pv. phaseoli, XTT: Xanthomonas translucens pv. translucens

$(+): 80 \%$ or more strains positive; (-): $\% 80$ or more strains negative; ND: not determined, V: variable

Table 3. Infestation Ratios (\%) of Pathogenic and Saprophytic Bacterial Strains on Seed Samples of Orange and Black Color Carrot Cultivars / Genotypes.

\begin{tabular}{|c|c|c|c|c|c|c|c|}
\hline & & \multicolumn{4}{|c|}{ Pathogenic bacteria } & \multicolumn{2}{|c|}{ Saprophytic bacteria } \\
\hline $\begin{array}{l}\text { Cultivar / } \\
\text { Genotype }\end{array}$ & $\begin{array}{l}\text { Sample } \\
\text { Number }\end{array}$ & $\begin{array}{c}\text { Infested } \\
\text { Seed Sample } \\
\text { with } X . h . \text { pv. } \\
\text { carotae }\end{array}$ & $\begin{array}{c}\text { Infestation } \\
\text { Ratio (\%) }\end{array}$ & $\begin{array}{l}\text { Infested Seed } \\
\text { Sample with } \\
\text { P. viridiflava }\end{array}$ & $\begin{array}{c}\text { Infestation } \\
\text { Ratio (\%) }\end{array}$ & $\begin{array}{l}\text { Infested seed } \\
\text { Sample with } \\
\text { Pseudomonas } \\
\text { spp. }\end{array}$ & $\begin{array}{c}\text { Infested } \\
\text { seed Sample } \\
\text { with } \\
\text { Bacillus spp. }\end{array}$ \\
\hline \multicolumn{8}{|c|}{ Orange carrot } \\
\hline Maestro & 10 & 2 & 20 & 1 & 10 & 9 & 3 \\
\hline Bolero & 4 & 1 & 25 & - & - & 6 & 2 \\
\hline Sireco & 3 & - & - & 1 & 33 & 1 & - \\
\hline Natuna & 3 & 1 & 33 & - & - & 3 & - \\
\hline Romans & 3 & - & - & 1 & 33 & 1 & 1 \\
\hline Total & 23 & 4 & - & 3 & - & 20 & 6 \\
\hline \multicolumn{2}{|c|}{ Infestation Ratio (\%) } & \multicolumn{2}{|c|}{17.39} & \multicolumn{2}{|c|}{13.04} & 86.95 & 26.08 \\
\hline \multicolumn{8}{|c|}{ Black carrot } \\
\hline Ereğli & 11 & 2 & 18 & 1 & 9 & 3 & 2 \\
\hline Total & 11 & 2 & - & 1 & - & 3 & 2 \\
\hline \multicolumn{2}{|c|}{ Infestation Ratio (\%) } & \multicolumn{2}{|c|}{18.18} & \multicolumn{2}{|c|}{9.09} & 27.27 & 18.18 \\
\hline
\end{tabular}

Ten samples out of total 34 samples were found to be infested with $X$. hortorum pv. carotae and $P$. viridiflava. Population of the bacterial pathogens in infested seed samples ranged from $3.2 \times 10^{5}$ to $5.6 \times 10^{8} \mathrm{CFU} / 20 \mathrm{~g}$ seed. The present study suggested considerable seed sample infestations (\%) with $X$. hortorum pv. carotae (on orange carrot seeds; $17.39 \%$ and on black carrot seeds; $18.18 \%$ ) and with $P$. viridiflava on orange and black carrot seeds as 13.04 and $9.09 \%$, respectively (Table 3).

Twenty three Pseudomonads and 8 Bacillus spp. as saprophytic bacteria were defined in orange and black carrot seeds. Antagonistic effects of these bacteria on $X$. hortorum pv. carotae and P. viridiflava were investigated on petri dishes, but remarkable results were not obtained.

\section{Colony morphology of bacteria}

$X$. hortorum pv. carotae on mTBM medium was observed after 7 days for colony characteristics. White, yellow, whitish-yellow, smooth, glistening, convex, round 1-2 mm diameter colonies with entire margins surrounded by a casein hydrolysis zone were observed. After 3-4 days of incubation at $28{ }^{\circ} \mathrm{C}$, typical mucoid and pale yellow growth of $X$. hortorum pv. carotae strains was observed on the YDCA medium. Glistening, smooth, round, straw yellow, 2-3 mm in diameter, and convex with entire margined colonies of $X$. hortorum pv. carotae were observed on the MD5A medium after 7-8 days. On MKM medium, 2-4 $\mathrm{mm}$ in diameter, light brown to peach yellow, light yellowcream, and round colonies of $X$. hortorum pv. carotae were seen after 6 days.

On King's medium B, thirteen $P$. viridiflava strains formed mucoid colonies, and produced fluorescent pigment when observed under UV light. The $\mathrm{KOH}$ reaction test confirmed that the strains were Gram- 
negative. Levan-type colonies were not observed for test bacterial strains on sucrose nutrient agar. On nutrient agar plus $40 \mathrm{mg} / \mathrm{L}$ of cycloheximide plates, convex, circular, and creamy colored colonies were observed after 3-5 days of incubation at $27^{\circ} \mathrm{C}$.

\section{Biochemical and physiological characteristics}

Total twenty-nine $X$. hortorum pv. carotae and $P$. viridiflava strains isolated from orange and black carrot seeds were identified by biochemical and physiological tests (Table 2).

Sixteen $X$. hortorum pv. carotae strains gave negative results from fluorescent pigment production on $\mathrm{KB}$ medium, facultative growth and pectolytic activity test. However, they were positive for starch and gelatin hydrolisis, and $\mathrm{H}_{2} \mathrm{~S}$ production from cysteine. The strains did not produce acid from adonitol, arabinose and sorbitol. Almost all strains gave identical results in these tests and the biochemical profiling to the X. hortorum pv. carotae reference strain. Obtaining data, only two (Xhcbc14 and Xhcoc3) out of twenty-one X. h. pv. carotae strains gave different results for gelatin hydrolysis test compare to reference strains (Table 2).

All strains were positive for catalase test and negative for oxidase and arginine dihydrolase activity tests. The strains were able to produce acid from sorbitol but not from sucrose. The strains were positive for pectolytic activity based on the ability to cause soft rot on potato slices. Results of these tests along with biochemical profiling of the test isolates were identical to the reference strain of $P$. viridiflava and were differentiated from negative references (Table 2).

Pathogenicity and HR reaction of $X$. hortorum pv. carotae and $P$. viridiflava strains

At first, the symptoms of $X$. hortorum pv. carotae on inoculated leaves appeared as small irregular yellowish water-soaked lesions with a tiny light brown spot in the center, which, in case of leaf spots enlarged at a later stage and became necrotic surrounded by a yellow halo. Eleven out of sixteen $X$. hortorum pv. carotae strains were pathogenic on leaves of cv. Maestro. Re-isolation of bacteria from inoculated plants confirmed the same as the inoculated ones.

Areas observed around the points of inoculation with $P$. viridiflava were light to dark brown. The roots' degradation was seen progressing from crown to the root tip when longitudinal sections were examined. Nine
P. viridiflava strains out of thirteen were pathogenic on the roots on cv. Maestro. Re-isolations made from the artificially infected plants yielded pure cultures.

In HR tests, all bacterial strains that caused necrosis on tobacco leaves and brown, collapsed areas of tissues were observed at the injection sites after $48 \mathrm{~h}$ of incubation at $28{ }^{\circ} \mathrm{C}$ and $80 \% \mathrm{RH}$.

\section{PCR Assays}

Characterization of $X$. hortorum pv. carotae and $P$. viridiflava strains by PCR showed that all $X$. hortorum $\mathrm{pv.}$ carotae strains amplified with the primers 3SF and 3SR and almost all $P$. viridiflava strains (except str. PvBc6) reacted with the primers PVF/ PVR. X. hortorum pv. carotae strains gave a product size of $350 \mathrm{bp}$ with the specific primers, 3SF and 3SR. An $860 \mathrm{bp}$ PCR amplified fragment of $P$. viridiflava strains using PVF1/PVR1 primers designed for $16 \mathrm{~S}$ rRNA sequence.

\section{DISCUSSION}

Carrot is among the top-ten economically important crops worldwide. According to agricultural statics, Turkey has an important place in the world carrot production (TUIK, 2019). Seventy percent of Turkey's carrots are produced in Konya province and are exported to the Balkans countries and Middle East (Livaneli, 2011).

Bacterial blight of carrot, caused by seedborne $X$. hortorum pv. carotae bacterial pathogen (Kendrick, 1934), concerns carrot growers in many regions of the world (Gilbertson, 2002; Cubeta and Kuan, 1986; Watson, 1948; Saad and Wade, 1972; Nishiyama et al., 1979; Meng et al., 2004). The pathogen can infect the seed internally or contaminate the seed surface, affecting the yield (Ark and Gardner, 1944; Umesh et al., 1998). Reduction of seed germination due to the infection by $X$. hortorum pv. carotae can result in significant losses to the farmers (Crowe and Bafus, 2004). Unfortunately, there is insufficient knowledge about the epidemiology of $X$. hortorum pv. carotae about carrot seeds. It is thought that the surface infestations probably take place during seed development in umbel and harvesting operations. True infection of inner seed tissues would start during early seed development, perhaps during the living connection of seed with mother plant or via pollen or nectar (Bashan and Okon, 1986). Since the Central Anatolia region has hot and dry conditions, bacterial 
diseases are seen at very low rates, and therefore, the symptoms of the disease are often not noticed in field conditions which are mistaken for the absence of the pathogen. In this regard, it should be emphasized that the disease can reach serious dimensions, especially in high irrigation conditions, humid and cool regions, and regions with different climatic conditions.

Melon and tomato crops foliage can be reduced up to $50 \%$ as a result of infection by $P$. viridiflava that causes extensive tissue necrosis (Goumans and Chatzaki, 1998). The opportunistic behavior of $P$. viridiflava allows it to survive on surfaces of its host or other weeds that can act as an inoculum source. P. viridiflava was responsible for severe economic losses to refrigerated carrot export from New Zealand by causing soft rot (Godfrey and Marshall, 2002). In Brazil, symptoms of $P$. viridiflava during post-harvest storage on potatoes were described by Macagnan et al. (2007) and observed the infection symptoms on chayote, sweet potato, yam, and pumpkin when inoculated the pathogen artificially. Association of $P$. viridiflava with carrot seeds may explain that postharvest losses can originate from contaminated seeds (Almeida et al., 2013).

Demir and Ustun (2001) tested a total of two thousandfour hundred-sixty-nine plant propagative units for the presence of some plant pathogenic bacteria. They detected Pseudomonas viridiflava in 3 samples (cauliflower and cabbage seeds), X. hortorum pv. carotae in one carrot seed sample in Aegean Region. Kurt et al. (2004) obtained Erwinia spp. and fluorescent and nonfluorescent plant pathogenic Pseudomonas spp. strains from diseased carrot roots, in the Eastern Mediterranean region.

In present study, to the best of our knowledge, this is the first report of $P$. viridiflava associated with carrot seeds in Turkey. As like X.h. pv. carotae, a high level of infestation was determined on orange and black carrot seeds by $P$. viridiflava as $9.09 \%$ and $13.04 \%$, respectively. Lack of such studies increases the significance of the present work in Central Anatolia.

The production of commercial carrot crops depends greatly on planting seeds with zero or low contamination of $X$. hortorum pv. carotae. In this study, high infestation ratios of $X$. hortorum pv. carotae on orange and black carrot seed samples were determined, between $17.39 \%$ and $18.18 \%$ respectively (Table3). In that region, most cultivated orange carrot cultivar is Maestro, and according to findings, this cultivar was infested with both $X$. hortorum pv. carotae and $P$. viridiflava. In order to control these diseases, necessary measures should be considered timely.

Twenty three orange and black carrot seed samples were infested with saprophytic bacteria, Pseudomonads and Bacillus spp. They did not show any antagonistic effect on pathogenic bacteria under in vitro conditions but they can cause decay on seeds at non-suitable storage conditions because of their high infestation (\%) in the seeds $(18.18 \%-86.95 \%)$ respectively (Table 3$)$.

The standard procedure for detection currently in use includes seed-wash dilution plating assay, together with pathogenicity tests of representative $X$. hortorum pv. carotae colonies. Although effective in general, this procedure is laborious and can take as long as one month to complete (Meng et al., 2004). In the present study, King's B, Nutrient Agar, MD5A, MKM, mTBM, and YDCA media were used for isolation and characterization of bacterial colony morphology. The strains were identified by biochemical, physiological pathological and HR tests for all $X$. hortorum pv. carotae, $P$. viridiflava and saprophytic bacteria.

Thus, development of more rapid PCR-based methods for detection and identification of seed contaminated by the pathogens should improve the capacity to detect and manage carrot bacterial diseases. PCR with the 3S primer pair could greatly reduce the time and facilities required for routine detection and identification of $X$. hortorum pv. carotae and could be used in ecological and epidemiological studies (Meng et al., 2004). In this study, the 3S primer pair were highly specific, and the about 350-bp target fragment amplified from all strains. Likewise PVF/PVR primers set confirmed $P$. viridiflava strains. The observations of present study suggested that PCR experiments were same to those reported by Goss et al. (2005). The PCR-based assays have the potential to improve routine detection of important carrot pathogens.

Epiphytic growth of $X$. hortorum pv. carotae is promoted under semi-arid areas where carrot seeds are produced (du Toit et al., 2005). The bacterial association with the seeds acts as an inoculum to cause bacterial blight when carrots are grown in humid and warm areas. Carrot seed produced in Turkey harbors $X$. hortorum pv. carotae so there is a dire need to identify the primary inoculum source to avoid future infections when grown under semi-arid regions of Turkey. Identifying these sources of infection and the primary periods of infection through 
the biennial season will assist in the development of more efficacious, regional integrated pest management programs for carrot seed crops.

Black carrots are a source for natural food coloring from Turkey and other regions of the Middle East and Asia. In Turkey, black colour carrot is produced in only Ereğli district of Konya Province and the growers use the genotypes of cv. Ereğli as seed. This situation contains two important problems; first, genetic expansions and susceptibilities to plant diseases as the same seeds are being used for many years. Second, transmission of fungal, bacterial and viral pathogens, both plant and human pathogens, from year to year and field to field. Further studies will be conducted to determine pathogens related to plant and human health, carrot yield, and orange carrots.

Plantation of healthy seed or treated seed can be an important strategy to manage bacterial blight (Umesh et al., 1998; Gilbertson, 2002; Meng et al., 2004). Other management recommendations include 2 to 3 year crop rotations, applications of copper bactericides, avoiding overhead irrigation that promotes dispersal of the bacterium and creates favorable conditions for infection and incorporating residues into the soil promptly after harvest (Parks and Crowe, 1999; Gilbertson, 2002; Weber et al., 2004). Seed can be disinfected by hot water treatment $\left(52{ }^{\circ} \mathrm{C}\right.$ for up to $25 \mathrm{~min}$ ) (Ark and Gardner, 1944; Gilbertson, 2002; Pscheidt and Ocamb, 2001). Limited resistance to bacterial leaf blight is available in some commercial cultivars. There is no study to determine susceptible or resistant carrot cultivars to fungal, bacterial or viral diseases in Turkey. This will become very important for future.

In subsequent experiments, authors plan to focus on the use of resistant cultivars for carrot bacterial diseases. Cultivar resistance is the most desirable for its costeffectiveness and long-term stability. The development of resistant cultivars requires advanced planning in breeding programs to incorporate and maintain a diverse range of resistance genes in parental lines, but little is known about carrot resistance to bacterial diseases. Therefore, further studies should be conducted primarily between carrot varieties and $X$. hortorum pv. carotae and $P$. viridiflava interactions.

\section{CONCLUSION}

Bacterial pathogens of carrot cause important damages on plant yield and seed quality. This study was conducted for detection and identification of seed borne bacterial pathogens on orange and black carrot seeds sown in Ereğli and Kaşınhanı districts of Konya province where the highest carrot production is obtained. Based on morphological, physiological, biochemical, pathological and molecular tests, the pathogenic agents were identified as Xanthomonas hortorum pv. carotae and Pseudomonas viridiflava with high percent infestation ratios. This to our knowledge is the first report of the occurrence of $P$. viridiflava on carrot seeds in Turkey. The information will be useful about using carrot seeds and required precautions to growers and authorities to get more healthy products and seeds.

\section{REFERENCES}

Ahmad, T., M. Cawood, Q. Iqbal, A. Ariño, A. Batool, R. M. S. Tariq, M. Azam and S. Akhtar. 2019. Phytochemicals in Daucus carota and their health benefits. Foods, 8: 1-22.

Alivizatos, A. 1986. Tomato pith necrosis caused by Pseudomonas viridiflava. Annales de l'Institut Phytopathologique Benaki, 15: 40-47.

Almeida, I., K. Maciel, J. R. Neto and L. Beriam. 2013. Pseudomonas viridiflava in imported carrot seeds. Australasian Plant Disease Notes, 8: 17-19.

Ark, P. and M. Gardner. 1944. Carrot bacterial blight as it affects the roots. Phytopathology, 34: 415-20.

Asma, M. 2010. Detection of Xanthomonas hortorum pv. carotae on Daucus carota international rules for seed testing. Seed Health Testing Methods International Seed Testing Association (ISTA). Bassersdorf, Switzerland.

Asma, M., R. de Vogel, B. Woudt and D. Krause. 2002. Evaluation of pathogenicity testing, repfingerprinting and PCR for the identification of Xanthomonas campestris pv. carotae, ISHI Report Bejo Zaden BV. Research Report, 9: 317-26.

Aysan, Y. 2001. Bacterial stem necrosis of tomato in the greenhouse in the eastern Mediterranean region of Turkey. 11th Congress of the Mediterranean Phytopathological Union and 3rd Congress of the Sociedade Portuguesa de Fitopatologia, Tekirdag, Turkey.

Aysan, Y., M. Mirik, A. Ala, F. Sahin and O. Cinar. 2003. First report of Pseudomonas viridiflava on melon in Turkey. Plant pathology, 52: 800-00.

Baker, K. F. and S. H. Smith. 1966. Dynamics of seed transmission of plant pathogens. Annual Review 
of Phytopathology, 4: 311-32.

Bashan, Y. and Y. Okon. 1986. Internal and external infections of fruits and seeds of peppers by Xanthomonas campestris pv. vesicatoria. Canadian journal of botany, 64: 2865-71.

Bradbury, J. F. 1986. Guide to Plant Pathogenic Bacteria. $\mathrm{CAB}$ International.

Crowe, F. and R. Bafus. 2004. Evaluation of the Potential for Systemic Infection of Carrot Seed Crops by Xanthomonas campestris pv. carotae. Central Oregon Agricultural Research Center. USA, pp. 1.

Cubeta, M. and T. Kuan. 1986. Comparison of MD5 and XCS media and development of MD5A medium for detection of Xanthomonas campestris pv. carotae in carrot seed. Phytopathology, 76: 1109-09.

Demir, G. and N. Ustun. 2001. Pathogenic bacteria that determined in imported and exported plant propagation material. Journal of Turkish Phytopathology, 30: 60-72.

du Toit, L. J., F. J. Crowe, M. L. Derie, R. B. Simmons and G. Q. Pelter. 2005. Bacterial blight in carrot seed crops in the Pacific Northwest. Plant Disease, 89: 896-907.

FAOSTAT. 2019. Food and agriculture organization of the United Nations. FAOSTAT Statistics Database.

Gilbertson, R. 2002. Bacterial Leaf Blight of Carrot. American Phytopathological Society: St. Paul, MN, USA.

Godfrey, S. and J. Marshall. 2002. Identification of coldtolerant Pseudomonas viridiflava and P. marginalis causing severe carrot postharvest bacterial soft rot during refrigerated export from New Zealand. Plant pathology, 51: 155-62.

Goss, E. M., M. Kreitman and J. Bergelson. 2005. Genetic diversity, recombination and cryptic clades in Pseudomonas viridiflava infecting natural populations of Arabidopsis thaliana. Genetics, 169: 21-35.

Goumans, D. and A. Chatzaki. 1998. Characterization and host range evaluation of Pseudomonas viridiflava from melon, blite, tomato, chrysanthemum and eggplant. European Journal of Plant Pathology, 104: 181-88.

Goumas, D., N. Malathrakis and A. Chatzaki. 1999. Characterization of Pseudomonas viridiflava associated with a new symptom on tomato fruit. European Journal of Plant Pathology, 105: 927-32.

Howard, R., J. Garland and W. Seaman. 1994. Diseases and Pests of Vegetable Crops in Canada. Canadian
Phytopathological Society: Ottawa, Canada.

Kaçar, B. and V. Katkat. 1999. Gübreler ve Gübreleme Tekniği, Uludağ Ünv. Güçlendirme Vakfı Yayınları: Bursa, Turkey.

Kendrick, J. B. 1934. Bacterial blight of carrot. Journal of Agricultural Research, 49: 493-510.

Kim, H., M. Sasser and D. Sands. 1982. Selective medium for Xanthomonas campestris pv. translucens. Phytopathology.

King, E. O., M. K. Ward and D. E. Raney. 1954. Two simple media for the demonstration of pyocyanin and fluorescin. The Journal of laboratory and clinical medicine, 44: 301-07.

Klement, Z. 1963. Rapid detection of the pathogenicity of phytopathogenic pseudomonads. Nature, 199: 299-300.

Klement, Z., K. Rudolph and D. Sands. 1990. Methods in Phytobacteriology. Akademiai Kiado.

Komagata, K. 1986. Genus Curtobacterium. In, Bergey's manual of systematic bacteriology.

Kovacs, N. 1956. Identification of Pseudomonas pyocyanea by the oxidase reaction. Nature, 178: 703-03.

Kuan, T.-L., G. Minsavage and R. Gabrielson. 1985. Detection of Xanthomonas campestris pv. carotae in carrot seed. Plant Disease, 69: 758-60.

Kuan, T. 1989. Detection of Xanthomonas campestris pv. carotae in carrot. In, Detection of Bacteria in Seed and Other Planting Material. American Phytopathological Society. St. Paul, MN, USA.

Kurt, S., E. M. Soylu, S. Soylu, F. M. Tok and F. Sahin. 2004. Determination of causal diseases agent on carrot plants growing in Amik Plain. Turkey 1st Plant Protection Congress Proceedings, Samsun.

Lelliott, R. A. and D. E. Stead. 1987. Methods for the Diagnosis of Bacterial Diseases of Plants. Blackwell Scientific Publications.

Livaneli, U. 2011. Most carrots in Turkey produced in Konya.

Macagnan, D., R. d. S. Romeiro, D. M. d. Macedo and D. A. Schurt. 2007. Podridão-mole em pós-colheita de batata (Solanum tuberosum) incitada por Pseudomonas viridiflava. Summa Phytopathologica, 33: 307-08.

Meguire, R., J. Jones and M. Sasser. 1986. Tween media for semi-selective isolation of Xanthomonas campestris pv. vesicatoria from soil and plant metarial. Plant Disease, 70: 887-89. 
Meijerink, C. and E. Van Breukelen. 1995. Seedborne diseases: International Initiative standardizes test protocols. Prophyta. The Annual, 49: 58-65.

Meng, X., K. Umesh, R. Davis and R. Gilbertson. 2004. Development of PCR-based assays for detecting Xanthomonas campestris pv. carotae, the carrot bacterial leaf blight pathogen, from different substrates. Plant Disease, 88: 1226-34.

Mundt, J. O. and N. F. Hinkle. 1976. Bacteria within ovules and seeds. Applied and Environmental Microbiology, 32: 694-98.

Nishiyama, K., T. Fukunishi, T. Terada and A. Ezuka. 1979. Bacterial blight of carrot Daucus carota var. sativa caused by Xanthomonas carotae a bacterial disease new to Japan. Japanese Journal of Phytopathology, 45: 683-88.

Parks, R. and F. Crowe. 1999. Sensitivity of Xanthomonas campestris pv. carotae to copper pesticides in central Oregon carrot seed fields. Oregon State University, Integrated Plant Protection Center.

Pscheidt, J. W. and C. M. Ocamb. 2001. Pacific Northwest Disease Management Handbook. Oregon State University: Oregon, USA.

Saad, S. M. and E. K. Wade. 1972. Bacterial blight of carrot in Wisconsin. Plant Disease Reporter, 56: 744-46.

Schaad, N. W. 1988. Initial Identification of Common Genera. In, Laboratory Guide for Identification of Plant Pathogenic Bacteria. American Phytopathological Society Press. St. Paul. MN. USA.

Schaad, N. W., J. B. Jones and W. Chun. 2001. Laboratory guide for the identification of plant pathogenic bacteria. American Phytopathological Society: St. Paul, MN, USA.

Strandberg, J. O. 2000. Carrot (Daucus carota L. subsp. sativus

(Hoffm.)

Arcang.). www.apsnet.org/publications/commonnames/pa ges/carrot.

Taylor, J. 1970. The quantitative estimation of the infection of bean seed with Pseudomonas phaseolicola (Burkh.) Dowson. Annals of Applied Biology, 66: 29-36.

Thornley, M. J. 1960. The differentiation of Pseudomonas from other Gram-negative bacteria on the basis of arginine metabolism. Journal of Applied Bacteriology, 23: 37-52.

TUIK. 2019. www.tuik.gov.tr, Accessed 15.12.2021.

Umesh, K., R. Davis and R. Gilbertson. 1996. Seed contamination thresholds associated with occurrence of bacterial blight of carrots and development of a DNA based detection method for Xanthomonas campestris pv. carotae. Abstract Phytopathology.

Umesh, K., R. Davis and R. Gilbertson. 1998. Seed contamination thresholds for development of carrot bacterial blight caused by Xanthomonas campestris pv. carotae. Plant Disease, 82: 1271-75.

Ustun, N. and H. Saygili. 2001. Pith necrosis on greenhouse tomatoes in Aegean region of Turkey. 11th Congress of Mediterranean Phytopathological Union and 3rd Congress of Sociedade Portuguesa de Fitopatologia.

Watson, R. 1948. Carrot bacterial blight control in Idaho. Plant Disease Reporter, 32: 338-39.

Weber, C. E., M. Butler, C. Campbell, B. Holliday and J. Klauzer. 2004. Management guide for drip irrigation on seed carrots in central Oregon. Oregon State University EM 8880-E, Corvallis.

Williford, R. and N. Schaad. 1984. Agar medium for selective isolation of Xanthomonas campestris pv. carotae from carrot seeds. Phytopathology, 74: 1142-42.

\section{CONFLICT OF INTEREST}

The authors declare that they have no known competing financial interests or personal relationships that could have appeared to influence the work reported in this paper

\section{AUTHORS CONTRIBUTIONS}

Kubilay Kurtulus Bastas: Funding acquisition, Resources, Project administration, Writing - review \& editing; Haris Butt: Data curation, Formal analysis, Writing - review \& editing; Aysegul Gur: Data curation, Formal analysis.

Publisher's note: EScience Press remains neutral with regard to jurisdictional claims in published maps and institutional affiliations.

Open Access This article is licensed under a Creative Commons Attribution 4.0 International License. To view a copy of this license, visit http://creativecommons.org/licenses/by/4.0/. 